\title{
Bank Level Challenges on Management of Loan Quality in Public Sector Banks
}

\author{
D. Yamuna, S. Subramanian
}

\begin{abstract}
This Paper investigates the challenges faced by public sector banks in India on Management of loan quality. The focal point of a financial institution is purely based on credit growth, CASA Ration and viable environment to enhance the overall bank performance. But the formation of non-performing assets affects the loan quality severely. The Formation of Non-Performing Assets is seen as a crucial part of banks and the magnitude would expose to various levels of risks across the nation's activities. The past literature discussed on determinants of non-performing assets, in terms of factors influencing by macroeconomic factors, borrower's centric factors, and bank-specific factors. On which a few kinds of literature focused on what are the bank-level challenges to maintain asset quality

To answer the research objectives, the structured questionnaire framed for the dimensions were taken all legal measures and bank level challenges factors to examine the study. A total of 135bank officials of different public sector banks branches were contacted and 100 responses were received. The data collected was subjected to statistical analysis. The results showed that all the causes for NPA are prominent; inappropriate Legal Measures and asset quality tools required careful scrutiny to reduce risk of NPA.
\end{abstract}

Index Terms: Non Performing Assets, Legal Measures, Asset quality dimensions-predictive and preventive- Public Sector Banks.

\section{INTRODUCTION}

The focus of banking regulation and framework has to promote the deployment of deposits and maintenance of loan quality. The regulatory framework plays a vital role in economic development. During post-financial sector reforms (1991) phase, various initiatives were made to strengthen the performance of banks and improve the firm's structure perceptibly. Financial soundness favours Indian banking system compared with other advanced and emerging countries.

The government's regulation policy for banks has paid rich dividends with the nationalization of 14 major private banks in 1969. Based on the recommendations of the Narasimham Committee, it is suggested that the banks have to maintain the transparency in financial reporting with the inclusion of asset qualification, income recognition and provisioning norms, which helps to identify and reduce bad loans. And that initiation improves the attention on asset quality problems.

\section{FACTS OF LOAN QUALITY IN PUBLIC SECTOR BANKS:}

\section{Revised Manuscript Received on July 05, 2019}

D. Yamuna, Research Scholar, Bharathiar School of Management and Entrepreneur Development (BSMED), Bharathiar University, Coimbatore, India.

Dr. S. Subramanian, Research Supervisor, Bharathiar School of Management and Entrepreneur Development (BSMED), Bharathiar University, Coimbatore, India.
- The accumulation of bad loans in our entire banking structure is accelerating year on year. Starting from public sector banks to till RRB's, the problem is still persistent. The allocations of bad loans were clearly stated in the RBI financial stability report (2018).

- Over the period from 2008 to 2018 , the performance of public sector banks was deteriorating and their credit delivery was reduced to $65 \%$ as on $31^{\text {st }}$ March, 2018 due to the heavy burden of bad loans. RBI listed 11 banks under Prompt Corrective Action (PCA) framework, those are severely affected by financial issues.

- The public sector banks were raised their provision coverage ratio to yield profitability, Recent prudential framework for resolution of stressed assets (June 2019) were supported banks to extend provisioning norms to restructured assets which are still in Resolution plan (RP).

- The Basel III norm has also tightened the CRAR, credit growth and recognition of stressed assets, to meet the global standards. On a global context, top 16 to 17 countries trying to meet Basel norms. India is one among 150 countries as on 2018 financial year.

The aforesaid facts represent the current situation of the asset quality of banks. Steps taken by Reserve Bank of India to were found meagre in front of mounting of Nonperforming assets.

\section{LITERATURE REVIEW}

Present literature has thrown some insights on the determinants of loan defaults. Hancock (1995) pointed out the inadequacies of the legal system are prominent in many counties which leads to serious problem in financial markets, followed by Boucher et.al(2009) stated that when the legislation is not providing adequate financial disclosure about borrowers that influence the occurrence of adverse selection of borrower and moral hazards activities. Mukerjee (2003) mentioned two types of strategy for the recovery of stressed assets through the formation of the asset management company (AMC) and decentralised credit-led strategy. He quoted that banks in India prefer the second strategy to resolve the bad loans. And there is a huge difference between private sector banks approaches with public sector banks approaches in terms of handling bad loans. Private Banks shows great interest in strict vigilance policy for screening borrowers and credit risk management system to facilitate the reduction of NPA were traced by (Romy, 2014). The bank-specific factors $\mathrm{Viz}$, adoption of prudential norms are not enough to describe the criticality of inter-bank variability of NPA especially in nationalised banks 
(Rajaraman, 2002). Folkerts et.al (1995) pointed that the banks in Asia possess inability on the exposure of connected lending because of the absence of scrutinizing the fake accounts or siphoning off funds and unable to find out where the funds are used.

P.N. Joshi(1999) studied the absence of proper recovery of bad loans is due to the inefficient legal system. It is found that persuasion on delayed loan recovery has given rise to liberal benefits to wilful defaulters. The DRT become ineffective due to non-punishment of wilful defaulters and intricate social stigma to nations. The banks have no alternatives other than compromise with wilful defaulter in order to reduce NPA which leads to the settlement of debt and compromise of loans at a high social cost. Strengthening of official supervisory power, independent supervisory authorities and market-based monitoring of banks in relation to more transparency were positively associated bank efficiency (Barth (2013)

The study focuses on how banks face challenges to maintain asset quality in order to mitigate the NPA in the subsequent future.

\subsubsection{LEGAL MEASURES:}

The central banks have taken many measures legally by setting up Asset Reconstruction Companies (ARCs), Debt Recovery Tribunals (DRTs), Securitization Act, Compromise Settlement Schemes etc. The effective measures were initiated in the year 2000 to manage the menace of NPA. Further, limited studies have undertaken on the effectiveness of measures from the post-millennium period, including One Time Settlement/Compromise Scheme (2000), Debt Recovery Tribunals (originally established in 1993, were significant amendment carried out during the year 2003), Corporate Debt Restructuring (2001), SARFAESI (the Act was passed during 2002) and Asset Reconstruction Company (ARC).In 2018, the above said measures were revoked by RBI exclusion of SARFAESI ACT, Lok Adalat, and IBC. One Time Settlement/Compromise Scheme (2000) is the last resort for banks to recover the bad loans before the resolution process. The performance of the measures is mentioned below.

\section{LEGAL MEASURES FOR RECOVERY OF BAD LOANS}

\section{Lok Adalats}

The Lok Adalats helps to settle disputes of accounts which fall under the category of doubtful and loss assets, through compromise settlement up to an outstanding balance of Rs. 5 lakhs the loans are recovered. Lok Adalat constituted under the Legal Services Authorities Act, 1987 and settlement towards smaller loan accounts are made effectively. Bank cases up to Rs.20,00,000 were brought and efforts taken to convene Lok Adalats to settle the bad loans quickly.

\section{T-1: LOK ADALATS - LOANS RECOVERED (In}

Billion)

\begin{tabular}{|r|l|r|l|l|}
\hline Year & $\begin{array}{l}\text { No. of } \\
\text { cases } \\
\text { referred }\end{array}$ & $\begin{array}{l}\text { Amount } \\
\text { involved }\end{array}$ & $\begin{array}{l}\text { Amount } \\
\text { recovered* }\end{array}$ & $\begin{array}{l}\text { \% of } \\
\text { recovered }\end{array}$ \\
\hline 2013 & 840691 & 66 & 4 & 6 \\
\hline 2014 & 1636957 & 232 & 14 & 6 \\
\hline 2015 & 2958313 & 310 & 10 & 3 \\
\hline 2016 & 4456634 & 720 & 32 & 4 \\
\hline 2017 & 2152895 & 1058 & 38 & 4 \\
\hline 2018 & 3317897 & 457 & 18 & 4 \\
\hline
\end{tabular}

Source: RBI

p: provisional.

For the past five years, the recovery through Lok Adalat was increasing year on year with a minimum increase of $4 \%$ growth rate

\section{Debt Recovery Tribunals (DRT)}

DRT has powers to grant sanctions the disposal, transfer or creation of third-party interest by debtors in the properties charged to the creditor and to pass attachment orders. In case of non-realization of the loan amount the sales deal occur, the guarantor's assets or properties can be sold, as it mentioned in the loan contract. The special court established by the Government of India for the purpose of bank or financial institution loan recovery and the act was passed in January 2000 for enhancing the effectiveness of DRTs. Recently the establishment of new DRT centres to improves the speedy recovery of bad loans

In the year 2019, Banks can file a case under DRT with an outstanding amount of Rs. 10, 00,000. The threshold limit was extended to Rs. 20, 00,000. The tribunal follows stipulated procedures on the basis of the duty to act fairly. Six more DRT has been established to recover bad loans.

\section{T-2: LOANS RECOVERED THROUGH DRT (In} Billion)

\begin{tabular}{|l|l|l|l|l|}
\hline Year & $\begin{array}{c}\text { No. of } \\
\text { cases } \\
\text { referred }\end{array}$ & $\begin{array}{c}\text { Amount } \\
\text { involved }\end{array}$ & $\begin{array}{c}\text { Amount } \\
\text { recovered* }\end{array}$ & $\begin{array}{l}\% \text { of } \\
\text { recovered }\end{array}$ \\
\hline 2013 & 13408 & 310 & 44 & 14 \\
\hline 2014 & 28258 & 553 & 53 & 10 \\
\hline 2015 & 22004 & 604 & 42 & 7 \\
\hline 2016 & 24537 & 693 & 64 & 9 \\
\hline 2017 & 28902 & 671 & 164 & 24 \\
\hline $2018(\mathrm{p}$ & & & & 5.4 \\
\hline$)$ & 29551 & 1333 & 72 & 5 \\
\hline
\end{tabular}

Source: RBI

P: Provisional

The amount recovered through DRT was fluctuating over a period of five years. In the year 2016 and 2017, 
insolvency resolution process. Resolution of insolvent companies allows the lenders to recover dues partly

SECURITIZATION AND RECONSTRUCTION OF FINANCIAL ASSETS AND ENFORCEMENT OF SECURITY INTEREST (SARFAESI) ACT, 2002

The SARFAESI Act has been amended for the purpose of faster loan recovery. The banks can take possession, manage and sell defaulter's mortgaged property without the intervention of court/tribunal. If the borrower not mentioned property details properly are subject to imprisonment for three months.NPA loans with the outstanding amount above Rs. 1,00,000 and the amount which is less than $20 \%$ of the principal amount and the interest rate are not eligible to be dealt with this act. Any security interest created over agricultural land cannot proceed with the SARFAESI Act enables through DRT and NCLT

\section{T-3: LOANS RECOVERED THROUGH} SARFAESI ACT(in Billion)

\begin{tabular}{|l|l|l|l|l|}
\hline & $\begin{array}{l}\text { No. of } \\
\text { cases } \\
\text { referred }\end{array}$ & $\begin{array}{l}\text { Amount } \\
\text { involved }\end{array}$ & $\begin{array}{l}\text { Amount } \\
\text { recovered* }\end{array}$ & $\begin{array}{l}\% \text { of } \\
\text { recovered }\end{array}$ \\
\hline 2013 & 190537 & 681 & 185 & 27 \\
\hline 2014 & 194707 & 953 & 253 & 27 \\
\hline 2015 & 175355 & 1568 & 256 & 16 \\
\hline 2016 & 173582 & 801 & 132 & 17 \\
\hline 2017 & 80076 & 1131 & 78 & 7 \\
\hline $2018(\mathrm{p})$ & 91330 & 1067 & 265 & 24.8 \\
\hline
\end{tabular}

Source: RBI

p: provisional

There is a significant reduction in the number of cases registered during 2016 - 2017 and their recovery percentage were also decreased to $7 \%$ due to the opening of new tribunals and strengthen the digital presence of handling court cases.

\section{Asset Recovery Construction Industry Limited(ARCIL)}

A company were initiated with the objective of overtaking distressed assets from banks or financial institutions and convert into saleable assets. To buy out a troubled loan from banks, the ARC makes a special effort at recovering value from the assets, if required special legislation, with special powers for recovery. The aim of this ARCIL is to restructure the weak banks in order to divest the bad loan portfolio.

Under SARFAESI Act, 2002, Bank can purchase and sale of NPAs to Asset Reconstruction Companies (ARCs). The acquisition cost of book value of asset was increased up to $36 \%$ during 2017 prior to 2014(28.7\%). This indicates the banks had to incur lesser haircut on account of sale of bad loans.

\section{Insolvency And Bankruptcy Code Act (2016)}

Recent enforcement of the IBC Act has challenged tough defaulters and quicker insolvency procedure as made possible. The performances of IBC were not studied in the previous literature; in the last nine quarter 1858 cases were admitted to the corporate and also the salvage parts of company business after debt obligation has been met. The insolvency process allows the stressed company to start a new business with new promoters and helps to clean up the balance sheet.

A unified framework for resolving insolvency and bankruptcy were enacted in May 2016, Insolvency and Bankruptcy Code (IBC) followed by the establishment of the Insolvency and Bankruptcy Board of India as the regulator on October 01, 2017; RBI has given direction to banks to initiate the insolvency resolution process under IBC. The purpose of IBC is to establish the authenticity and accuracy of documents/records for the resolution process. IBBI chairman, M.S. Sahoo stated that the objective of bankruptcy law is to resolve insolvency and revive the assets for the collective good. IBC empowered creditors to deal with troubled financial assets in a transparent manner within a time frame (RBI report, 2018)

T-4: LOAN RECOVERED THROUGH IBC

\begin{tabular}{|l|l|l|l|l|} 
Year & $\begin{array}{l}\text { No. of } \\
\text { cases } \\
\text { referred }\end{array}$ & $\begin{array}{l}\text { Amount } \\
\text { involved }\end{array}$ & $\begin{array}{l}\text { Amount } \\
\text { recovered } \\
*\end{array}$ & $\begin{array}{l}\% \\
\text { recovered }\end{array}$ \\
\hline 2017 & $37^{@}$ & - & - & - \\
\hline $2018(\mathrm{p}$ & $701^{@}$ & $99^{\#}$ & $49^{\wedge}$ & 49.6 \\
\hline
\end{tabular}

Note:

P: Provisional

@: Case admitted by NCLT

\#: Claims admitted by Financial Creditors (FCs) on 21 companies for which resolution plan was approved

^: Realization by FCs from 21 companies for which resolution plan was approved

Source: RBI and IBBI Newsletter.

\section{OBJECTIVES}

1. To analyse the bank-level challenges faced by public sector banks.

2. To identify the legal measures preference among bankers to resolve NPA.

\section{RESEARCH METHODOLOGY}

On the basis of definitions, the researcher wants to identify the bank-level challenges and efficacy of measures undertaken by PSB to resolve the bad loans. Items were measured on a 5-point Likert scale, measure 1 as (Strongly disagree) and 5 (Strongly agree). Random sampling was done. The pilot study was used to assess the precision of the questions and the reliability of variables with respect to the questionnaire. In January 2018, a total of 50 responses were collected from a non-probability sample of bank officials of selected banks. Based on respondent feedback, adjustments to the questionnaire items were made. Cronbach's alpha was analyzed for all the factors, and items found to be unreliable were dropped. Details provided in the tables, T-. In summary, the questionnaire was improved on the basis of the findings of the pre-test. A total of 135 credit officers of public sector banks exclusion of private banks and foreign banks in 
Chennai were contacted, out Of the 135 , valid questionnaires answered by 100 respondents were considered for the tabulation of

\begin{tabular}{|l|r|r|}
\hline $\begin{array}{l}\text { Factors of Bank-level } \\
\text { Challenges }\end{array}$ & \multicolumn{1}{c|}{ Mean } & \multicolumn{1}{c|}{ SD } \\
\hline Poor Credit Assessment & 20.27 & 3.00 \\
\hline $\begin{array}{l}\text { Lack of Organisation } \\
\text { Learning }\end{array}$ & 16.45 & 2.40 \\
\hline $\begin{array}{l}\text { Lack of Trained } \\
\text { Employees }\end{array}$ & 13.15 & 1.73 \\
\hline Political Pressure & 12.67 & 2.32 \\
\hline Poor Credit Monitoring & 15.83 & 2.68 \\
\hline Intentional Default & $\mathbf{2 6 . 6 3}$ & $\mathbf{3 . 1 7}$ \\
\hline Contagious Default & 17.89 & 2.23 \\
\hline Moral Deprivation & 13.14 & 1.78 \\
\hline
\end{tabular}

\section{T- 5: CRONBACH ALPHA OF DIMENSIONS}

\begin{tabular}{|l|l|l|}
\hline Dimensions & $\begin{array}{l}\text { Number Of } \\
\text { Items }\end{array}$ & $\begin{array}{l}\text { Cronbach's } \\
\text { Alpha }\end{array}$ \\
\hline $\begin{array}{l}\text { Bank Specific } \\
\text { Factors }\end{array}$ & 8 & 0.928 \\
\hline Legal Measures & 6 & 0.759 \\
\hline
\end{tabular}

\begin{tabular}{|l|l|l|}
\hline & 14 & 0.982 \\
\hline
\end{tabular}

\section{RESULTS AND DISCUSSION}

\section{HYPOTHESES}

H0: There is no positive relationship between factors of bank-level challenges with reference to Public sector banks H1: There is no significant difference among mean rank towards legal measures preferences among Public Sector Banks

\section{T - 6: MEAN AND SD OF BANK-LEVEL CHALLENGES IN PUBLIC SECTOR BANKS}

Inference:

Based on the mean score, Intentional Default (26.63) is the most important factor of bank-level inadequacies at public sector banks, followed by poor Credit Assessment (20.27), Contagious Default (17.89) and poor Credit Monitoring (15.83) in the public sector banks and so on. The least factor is Political Pressure (12.67) followed by Moral Deprivation (13.14) and Lack of Training Employees (13.15) and so on. This indicates, the incidence of NPA occur mainly due to intentional default of the borrowers and poor credit assessment at public sector banks.

\begin{tabular}{|l|r|r|r|r|}
\hline $\begin{array}{l}\text { Factors of } \\
\text { Bank-level } \\
\text { challenges }\end{array}$ & \multicolumn{1}{c|}{$\begin{array}{c}\text { Credit } \\
\text { Assessment }\end{array}$} & $\begin{array}{c}\text { Overall } \\
\text { Adverse } \\
\text { Selection }\end{array}$ & $\begin{array}{c}\text { Overall } \\
\text { Credit } \\
\text { Monitoring }\end{array}$ & \multicolumn{1}{c|}{$\begin{array}{c}\text { Overall } \\
\text { Moral } \\
\text { Hazard }\end{array}$} \\
\hline Credit Assessment & 1.000 & $0.460^{* *}$ & $0.485^{* *}$ & $0.211^{* *}$ \\
\hline $\begin{array}{l}\text { Overall Adverse } \\
\text { Selection }\end{array}$ & $0.460^{* *}$ & 1.000 & $0.406^{* *}$ & $0.414^{* *}$ \\
\hline $\begin{array}{l}\text { Overall Credit } \\
\text { Monitoring }\end{array}$ & $0.485^{* *}$ & $0.406^{* *}$ & 1.000 & $0.263^{* *}$ \\
\hline $\begin{array}{l}\text { Overall Moral } \\
\text { Hazard }\end{array}$ & $0.211^{* *}$ & $0.414^{* *}$ & $0.263^{* *}$ & 1.000 \\
\hline
\end{tabular}

\section{CORRELATION ANALYSIS}

H1: There is a positive relationship between factors of bank-level challenges with reference to Public sector banks

\section{T-6: Pearson Correlation Coefficient between factors} of bank-level challenges in public sector banks Note: ** Denotes significant at $1 \%$ level

The correlation coefficient among factors of credit assessment is 0.460 , which indicate $46 \%$ percentage positive relationships between Credit assessments and overall adverse selection is significant at $1 \%$ level. The relationship between credit assessment and credit monitoring is 0.485 , which indicate 48.5 percentage positive relationships between credit assessment and credit monitoring which is significant at $1 \%$ level. The correlation analysis between Perception on the overall adverse selection and overall Moral Hazards is 0.414 , which indicate 41.4 percentage positive relationships between Perception on overall adverse selection and credit monitoring are significant at $1 \%$ level and similarly, the other factors are positively correlated with each other. This represents that, the factors on the incidence of NPA are highly correlated with other factors. The least correlation between moral hazards and overall credit monitoring, this shows based on a theoretical perspective when credit monitoring is strict, there is no occurrence of moral hazard in the organization. It's a cascading effect.

FRIEDMAN TEST:

H1: There is no significant difference among mean rank towards legal measures preferences among Public Sector Banks. 


\section{T-7: FRIEDMAN TEST FOR SIGNIFICANT DIFFERENCE AMONG MEAN RANKS TOWARDS PREFERENCES}

OF LEGAL MEASURES AMONG BANKERS TO RESOLVE BAD LOANS

\begin{tabular}{|c|c|c|c|}
\hline Preference of Legal Measures & Mean rank & Chi-square value & $\mathrm{P}$ value \\
\hline Recovery by way of a compromise settlement of accounts & 4.01 & \multirow{6}{*}{7.614} & \multirow{6}{*}{0.179} \\
\hline Filing of the suit in DRT & 3.47 & & \\
\hline $\begin{array}{l}\text { Enforcement of SARFAESI Act } 2002 \text { by the takeover of } \\
\text { assets and transfer of management }\end{array}$ & 3.35 & & \\
\hline Settlements through lok adalats & 3.44 & & \\
\hline $\begin{array}{l}\text { Transfer of assets to assets recovery companies (RC) \& } \\
\text { securitization companies (SC) }\end{array}$ & 3.39 & & \\
\hline Recovery NPA under IBC(2016) & 3.47 & & \\
\hline
\end{tabular}

Since $\mathrm{p}$ value is greater than 0.01 , the null hypothesis is accepted at $5 \%$ level of significance. Hence it is concluded that there is no significant difference among mean rank towards legal measures. This shows that legal measures are not appropriate to reduce NPA in terms of retail loans. The mean rank of recovery by way of compromise settlements of accounts (4.01) is higher than other legal measures. This indicates the banker prefer compromise settlements for reducing NPA. All legal measures are very meagre to resolve bad loans, the bankers chose the compromise settlements for the benefit of both parties (lenders and borrowers)

\section{MANAGERIAL IMPLICATION}

NPA affects bank in two ways, first is, it drains the Interest income and profitability and other is, it attract cost on account of recovery of bad loans (Mohan, 2012).

Based on statistical analysis it is found that the reasons for formation of NPA in public sector banks mainly due to inadequate loan monitoring and absence of consistent follow-up. The bankers' inability to identify the intention of defaulters towards non-payment of dues despite adequate cash flows and siphoning off funds. Borrowers have not used their loans appropriately for their original purpose.

The measures undertaken by banks were found to be preferred remedies to resolve bad loans. Though the number of measures is initiated by RBI and Government of India, at present, the public sector banks prefer recovery of loans by way of a compromise settlement of accounts. This infers how nationalised banks were conservative enough to tackle NPA.

\section{RECOMMENDATIONS AND CONCLUSION}

On account of managerial implications, the following recommendations have substantiated the necessity of resolving stressed loans. For the past decade, the threat of loans default arises among Indian banks due to various reasons, the extension of the loan portfolio in small loans emerges too. The method of appraising, fund disbursement were not the same for all loan segments but the banks, as well as regulators, expect applicability legal measures for all types of loans from where the problems start. The bank-level challenges are the main reason for the occurrence of NPA in public sector banks and preference for legal measures are meagre to resolve mounting bad loans. Baks has to consider tailor-made measures to each loan segment such as large borrowers, retail and corporate borrowers. Better asset quality plays a major role in resolving stressed loans. To strengthen asset quality, the banks have to consider the predictive analysis and pre-emptive analysis. Predictive measures focus on enhancing credit risk management and continuous risk assessment systems which will reduce the instances of fresh NPA that have been generated currently. The pre-emptive analysis supports the banks to overcome delinquency, sale of NPA, provide credit incentives to bank employees to motivate them to enhance the asset quality etc.

\section{CONCLUSIONS}

The results showed that the causes and preferred remedial measures to resolve NPA in retail loans are focused in the study had a different perspective on loan segment and its credit quality of Public sector banks.

\section{SCOPE FOR FUTURE STUDY}

Our study is limited to bank-specific factors. Borrowers - centric factors, macroeconomic factors etc. can be also addressed in future research. First, our sample is limited geographically restricted to public sector banks. Our hypotheses should be tested further in other metros and states to get a Pan India data on Indian banks.

\section{REFERENCES}

[1] Barth, J.R, Lin, C., Ma, Y., Seade, J., Song, F.M., (2013) "Does Bank Regulations, Supervision and Monitoring Enhance or Impede Bank Efficiency?" Journal of Banking and Finance, 37(8), pp. 2879-2892, online.

[2] Boucher. S.R, Guirkinger.C, Triveli.C,(2009) “ Direct Elicitation of Credit constraints: Conceptual and Practical issues with an application to Peruvian agriculture", Economic Development and cultural change, Col 57(4), pp 93-110.

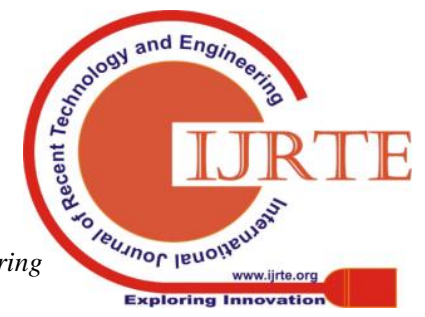


[3] Folkerts-Laudau, D, G.J. Schinasi, Cassard. M, Ng, V K, C M Reinhart, M.G. Spencer, (1995), “Effect of Capital flows on the domestic financial sectors in APEC Developing countries", in Khan and Reinhart (ed) (1995).

[4] Hancock. D, Laing A.J, J.A. Wilcox (1995), "Bank Capital Socks: Dynamic effects on securities, loans and capital", Journal of Banking and finance, 19(3-4), pp 661-677.

[5] Joshi, P.N., (1999). "Banking Sector Reforms: the other side of the coin” Economic and Political Review, 797.

[6] Mohan Kumar, Govind Singh (2012), "Mounting NPA in Indian Commercial Banks", International Journal of Transformation in Business Management, Vol.1, No.6, pp 1-18.

[7] Mukherjee. P(2003), "Dealing with NPAs: Lessons from International Experience", ICRA Bulletin, Money and Finance, pp.64-90.

[8] NPAs of Scheduled Commercial Banks Recovered through Various Channels, Reserve Bank of India, online: http://dbie.rbi.org.in.

[9] Rajaraman.I, Vasishtha.G (2002), "Non Performing loans of Public Sector Banks: Panel Results", Economic and Political Weekly, 37(5), pp. 429-435.

[10] Report on the committee on the financial system (1991) a high power committee appointed by Government of India, head by Narasimham.

[11] Romy Arora (2014), "Impact of Nonperforming assets: A Comparative Analysis of public sector banks and private sector banks", Indian Journal of Research, Vol.4, No. 2, pp. 106-108.

[12] Shashidhar M(2014) reemerging stress in the asset quality of Indian banks: macro-financial linkage WPS(DEPR): 03/2014, RBI working paper.

[13] Vikkraman P and Ganapathi R (2011), Attitude of customers towards the services of bankers regarding consumer loans, Rai management journal, 8(1), pp 4-32. 